\title{
Optimasi Peran Desa Adat di Bali melalui Teknologi Informasi
}

\author{
Kadek Darmaastawan ${ }^{1}$, Komang Oka Saputra ${ }^{2}$, Ni Made Ary Esta Dewi Wirastuti ${ }^{3}$ \\ [Submission: 10-05-2021, Accepted: 08-04-2021]
}

\begin{abstract}
Bali is famous for having various natural and cultural attractions. Balinese Traditional Village has a role in preserving Balinese culture because they routinely hold cultural activities such as performing arts and religious ceremonies. The rapid development of technology has brought modern products, such as the internet and smartphones, to Balinese Traditional Village. This development has had various positive impacts, for example, the ease of accessing information via the internet and information technology. Balinese Traditional Village can optimize their role in preserving Balinese culture through traditional activities by utilizing information technology. This study aims to obtain the potential for information technology that can optimize Balinese Traditional Village activities by reviewing previous research and conducting online surveys. The survey carried out involved 78 respondents from Balinese Traditional Village who differed from one another. The survey results show that only $18.3 \%$ of respondents have used information technology to manage Balinese Traditional Village activities. This research also provides suggestions in the form of information technology potential that can optimize Balinese Traditional Village activities to preserve Balinese culture.
\end{abstract}

Intisari- Bali terkenal karena memiliki berbagai objek wisata alam maupun budayanya yang khas. Desa Adat di Bali memiliki peran yang penting dalam melestarikan budaya khas Bali karena secara rutin mengadakan kegiatan budaya seperti pentas kesenian maupun upacara keagamaan. Perkembangan teknologi yang pesat telah membawa produk modern, seperti internet dan smartphone, hingga ke Desa Adat di Bali. Perkembangan tersebut memberikan berbagai dampak positif, contohnya adalah kemudahan dalam mengakses informasi melalui internet dan teknologi informasi. Desa Adat di Bali dapat mengoptimalkan perannya dalam melestarikan budaya melalui kegiatan adat dengan memanfaatkan teknologi informasi. Penelitian ini bertujuan untuk memperoleh potensi teknologi informasi yang mampu mengoptimalkan kegiatan adat dengan mengkaji penelitian terdahulu serta melakukan survei secara online. Survei yang dilakukan melibatkan 78 orang responden dari Desa Adat di Bali yang berbeda satu dengan yang lainnya. Hasil survei menunjukkan bahwa, hanya $18,3 \%$ dari responden yang telah memanfaatkan teknologi informasi untuk mengelola kegiatan adat. Penelitian ini juga memberikan saran berupa potensi teknologi informasi yang dapat mengoptimalkan kegiatan adat guna melestarikan Budaya Bali.

Kata Kunci- Desa Adat Bali, Budaya, Teknologi, Teknologi Informasi.

\footnotetext{
${ }^{1}$ Mahasiswa, Program Pasca Sarjana, Manajemen Sistem Informasi dan Komputer Fakultas Teknik Universitas Udayana, Jln. P. B. Sudirman, Denpasar, Bali, 80232 (telp: 0361-239599; email: kadek_darmaastawan@yahoo.com)

2, ${ }^{3}$ Dosen, Program Pasca Sarjana, Manajemen Sistem Informasi dan Komputer Fakultas Teknik Universitas Udayana, Jln. P. B. Sudirman, Denpasar, Bali, 80232 (telp: 0361-239599; email: ${ }^{2}$ okasaputra@unud.ac.id, ${ }^{3}$ dewi.wirastuti@unud.ac.id)
}

\section{PENDAHULUAN}

Bali merupakan sebuah provinsi di Indonesia yang dikenal oleh banyak negara. Hal tersebut dikarenakan Bali merupakan destinasi wisata dengan keunikannya tersendiri [1]. Objek wisata yang dapat dinikmati oleh wisatawan di Bali meliputi objek wisata alam maupun budaya seperti musik, pentas kesenian, hingga beberapa upacara keagamaan yang dapat dinikmati wisatawan ketika berkunjung ke Bali [2], [3]. Objek wisata di Bali secara umum dikelola oleh Desa Adat di bawah pembinaan dan pengawasan dinas pariwisata dan kebudayaan [4]. Desa Adat di Bali memiliki peran penting dalam melestarikan wisata budaya khas Bali, seperti kegiatan pentas kesenian maupun upacara keagamaan, sehingga kelestariannya tetap terjaga sampai saat ini [5], [6]. Hal tersebut disebabkan oleh Desa Adat yang secara rutin mengadakan kegiatan tersebut, dimana masyarakat Desa Adat secara bergotong-royong melaksanakan kegiatan tersebut mulai dari persiapan hingga kegiatan selesai [6].

Perkembangan zaman dan teknologi yang pesat telah membawa produk modern ke setiap sudut yang ada di seluruh dunia, tidak terkecuali Desa Adat di Bali [7]. Hal tersebut terbukti dengan mudahnya ditemukan berbagai produk hasil perkembangan teknologi yang digunakan oleh masyarakat Desa Adat di Bali, seperti contohnya adalah internet dan smartphone. Kedua teknologi tersebut dapat memberikan dampak positif bagi manusia, contohnya adalah kemudahan dalam mengakses informasi kapan dan dimana saja melalui internet dan teknologi informasi [8]-[11]. Seiring dengan dampak positif yang diberikan, teknologi tersebut juga tidak terlepas dari berbagai dampak negatif yang dapat ditimbulkan [12]. Oleh karena itu pemanfaatan teknologi harus dilakukan dengan baik dan benar untuk meminimalisir dampak negatif dari teknologi. Desa yang ada di Indonesia dituntut untuk mampu berinovasi dan memanfaatkan teknologi informasi dengan baik dan benar, sehingga dapat mengikuti arus globalisasi dan meningkatkan kinerja operasional desa serta meningkatkan kesejahteraan warga desa [13]-[15]. Penelitian [6] mengajukan sebuah solusi SI/TI yang diperoleh melalui analisis SWOT pada Desa Adat Kesiman. Solusi yang diajukan berupa saran sistem terintegrasi yang dapat mengakomodasi berbagai kegiatan di Desa Adat Kesiman. Kegiatan tersebut meliputi kegiatan administratif desa, hingga pengelolaan informasi desa untuk warga desa dan masyarakat luas, termasuk di dalamnya adalah informasi mengenai objek wisata.

Lebih lanjut disebutkan pada penelitian [6] bahwa masih terdapat Desa Adat di Bali yang belum memanfaatkan teknologi informasi untuk kegiatan internal maupun eksternal desa. Hal tersebut sangat disayangkan karena teknologi 
informasi dapat mengoptimalkan peran Desa Adat di berbagai aspek. Selama beberapa tahun terakhir, teknologi telah berkembang dan berubah secara signifikan, banyak teknologi baru yang muncul, namun tidak sedikit pula yang mulai dilupakan dan ditinggalkan. Di masa yang akan datang, masih banyak teknologi baru yang akan ditemukan dan akan menjadi tren baru [16]. Oleh karena itu, masih belum terlambat bagi suatu desa, khususnya Desa Adat di Bali, untuk memanfaatkan teknologi informasi dengan tujuan untuk mengoptimalkan peran Desa Adat seperti melestarikan budaya. Terlebih dengan adanya smartphone serta mudahnya akses internet di beberapa lokasi membuat informasi menjadi lebih mudah diperoleh oleh siapa, kapan, dan dimana saja. Melihat kemudahan dan manfaat yang dapat diberikan oleh teknologi informasi, penelitian ini akan mengkaji pemanfaatan teknologi informasi untuk mengoptimalkan peran Desa Adat di Bali.

\section{DeSA AdAT BALI}

Desa tradisional Bali atau biasa disebut dengan Desa Adat merupakan salah satu bentuk Kesatuan Masyarakat Hukum Adat (KMHA) yang diatur pada Pasal 18 B ayat (2) UUD NRI Tahun 1945 [17]. Pasal tersebut menyebutkan bahwa KMHA beserta hak-haknya diakui oleh negara dengan syarat sebagai berikut.

- Masih hidup.

- Tidak bertentangan dengan masyarakat.

- Sesuai dengan prinsip NKRI.

Masyarakat Desa Adat di Bali atau krama desa hidup dan tinggal bersama di suatu tempat dalam kurun waktu tertentu serta memiliki pandangan dan cara hidup yang sama [18]. Menurut Liefrinck yang disebutkan pada penelitian [19] menyatakan bahwa, Desa Adat di Bali bersifat otonom sehingga memiliki adat dan aturannya masing-masing dalam mengatur rumah tangganya. Desa Adat di Bali terbagi menjadi wilayah yang lebih kecil yang disebut dengan banjar. Setiap banjar memiliki pembagian wilayah yang lebih kecil yang disebut dengan tempekan untuk membagi dan menandakan tempat tinggal penduduknya.

\section{A. Banjar}

Banjar yang merupakan pembagian dari sebuah Desa Adat di Bali yang diketuai oleh seseorang yang disebut dengan Kelihan Banjar [19]. Banjar memiliki suatu sistem untuk mencapai kesejahteraan bersama dengan ikatan warga banjar atau disebut dengan krama banjar yang sangat erat. Sistem kesejahteraan tersebut berupa nilai, peraturan, serta mekanisme tertentu yang digunakan untuk memecahkan permasalahan kesejahteraan krama banjar. Peraturan tersebut biasa disebut dengan awig-awig yang harus ditaati oleh seluruh krama banjar [20]. Menyama braya merupakan istilah yang melandasi awig-awig serta pola hidup krama banjar. Menyama braya merupakan istilah yang menganggap seluruh krama banjar pada suatu banjar adalah saudara atau keluarga, dengan tidak memandang ikatan darah. Hal tersebut menyebabkan setiap krama banjar di suatu banjar wajib untuk menolong satu sama lain serta melakukan gotongroyong di berbagai situasi, sama halnya dengan keluarga yang sesungguhnya [21]. Banjar juga tidak memandang kondisi ekonomi dari setiap krama, sehingga setiap krama banjar memiliki hak serta kewajiban yang sama antara satu krama

ISSN $1693-2951$. dengan yang lainnya. Krama banjar_wajib memberikan sumber dayanya ke krama banjar lain, serta memiliki hak untuk menerima sumber daya dari krama banjar lain [20].

\section{B. Tempekan}

Tempekan merupakan pembagian kelompok-kelompok krama banjar yang diketuai oleh seseorang yang disebut dengan Kelihan Tempekan. Pengelompokan tempekan biasanya didasari atas deretan tempat tinggal krama banjar, dan biasanya menggunakan nama arah mata angin, sebagai contoh adalah Tempekan Kangin (Tempekan Timur), Tempekan Kauh (Tempek Barat), dan sebagainya [19].

\section{Peran Desa Adat di Bali}

Dilihat dari konsep Tri Hita Karana, yaitu konsep menjaga hubungan yang baik antara manusia dengan Tuhan, manusia lainnya, serta lingkungan sekitar untuk mewujudkan kesejahteraan. Desa Adat di Bali memiliki peran yang sangat penting untuk melestarikan budaya khas Bali. Peran tersebut tercermin pada landasan Desa Adat itu sendiri yaitu menyama braya untuk saling tolong-menolong dan gotong-royong, baik suka maupun duka [22]. Tolong-menolong dan gotong-royong tersebut dilakukan di berbagai kegiatan adat berikut ini untuk menerapkan konsep Tri Hita Karana [23] .

- Memperingati hari raya keagamaan yang merupakan hubungan manusia dengan Tuhan.

- Membantu pelaksanaan perkawinan atau kematian yang merupakan hubungan manusia dengan manusia, baik suka maupun duka.

- Melaksanakan kegiatan kerja bakti yang merupakan hubungan manusia dengan lingkungan.

Penelitian [24] juga menyebutkan krama banjar pada suatu Desa Adat dalam memperingati hari raya keagamaan biasanya akan berkumpul untuk bergotong-royong, yang dikenal dengan istilah ngayah, di bale banjar atau pura. Hal tersebut dilakukan untuk mepersiapkan semua kelengkapan upacara hari raya keagamaan hingga upacara berakhir. Tolongmenolong serta gotong-royong juga dilakukan apabila terdapat krama banjar yang akan melaksanakan upacara perkawinan maupun kematian. Krama banjar lain akan bergotong-royong untuk membantu krama banjar yang bersangkutan dari persiapan hingga upacara berakhir. Krama banjar juga biasa melaksanakan kerja bakti rutin secara gotong-royong untuk menjaga kebersihan lingkungan.

Selain dilihat dari konsep Tri Hita Karana, Desa Adat di Bali juga memiliki peran lain, yaitu peran di bidang pariwisata untuk mengelola objek wisata yang ada di area Desa Adat. Bali memiliki objek wisata dengan keunikannya tersendiri sehingga mampu menarik wisatawan dari berbagai negara seperti yang dijelaskan pada penelitian [2], [25]-[28], baik objek wisata alam maupun budaya. Objek wisata tersebut dikelola oleh Desa Adat bersangkutan di bawah pembinaan dan pengawasan dinas pariwisata dan kebudayaan [4]. Pengelolaan objek wisata tersebut meliputi pemberdayaan krama desa sebagai mayoritas staff lapangan, penetapan biaya operasional, dan pengelolaan hasil pendapatan dari objek wisata. Selain itu krama desa juga dapat melakukan promosi objek wisata di desanya sehingga lebih dikenal masyarakat luas [29].

Kadek Darmaastawan: Optimasi Peran Desa Adat... 


\section{METODOLOGI DAN PEMBAHASAN}

Bagian metodologi dan pembahasan akan memaparkan mengenai pemanfaatan teknologi informasi di sebuah desa. Teknologi informasi dapat diterapkan di suatu desa dan dapat mengakomodasi beberapa aspek yang ada di desa sehingga dapat membantu menunjang dan mengoptimalkan aspek tersebut. Contohnya adalah membantu dalam administrasi desa serta mengelola kegiatan yang ada di desa [6], [30]. Tabel 1 menyajikan rangkuman penelitian terdahulu terkait dengan pemanfaatan teknologi informasi di desa yang ada di Indonesia.

TABEL I

KAJIAN PENELITIAN PEMANFAATAN TEKNOLOGI INFORMASI Di DESA

\begin{tabular}{|c|c|c|c|}
\hline Penulis & Platform & Aspek Desa & Tujuan \\
\hline \multirow[t]{2}{*}{$\begin{array}{l}\text { Rozi dan } \\
\text { Listiawan [30] }\end{array}$} & \multirow[t]{2}{*}{$\begin{array}{l}\text { Aplikasi } \\
\text { website }\end{array}$} & $\begin{array}{l}\text { Pengarsipan } \\
\text { berkas }\end{array}$ & $\begin{array}{l}\text { Mempermudah } \\
\text { pencarian data } \\
\text { penduduk desa }\end{array}$ \\
\hline & & $\begin{array}{l}\text { Informasi } \\
\text { desa }\end{array}$ & $\begin{array}{l}\text { Mempermudah } \\
\text { akses informasi } \\
\text { desa oleh } \\
\text { masyarakat } \\
\text { desa }\end{array}$ \\
\hline \multirow[t]{4}{*}{$\begin{array}{l}\text { Sudiarsa et al } \\
{[6]}\end{array}$} & \multirow[t]{4}{*}{$\begin{array}{l}\text { Aplikasi } \\
\text { website }\end{array}$} & $\begin{array}{l}\text { Pengarsipan } \\
\text { berkas }\end{array}$ & $\begin{array}{l}\text { Mempermudah } \\
\text { pencarian } \\
\text { berkas, seperti } \\
\text { berkas kegiatan } \\
\text { masyarakat }\end{array}$ \\
\hline & & Perpustakaan & $\begin{array}{l}\text { Mempermudah } \\
\text { akses pustaka } \\
\text { desa }\end{array}$ \\
\hline & & Keuangan & $\begin{array}{l}\text { Membantu } \\
\text { penganggaran, } \\
\text { pelaksanaan } \\
\text { perolehan } \\
\text { pendapatan dan } \\
\text { belanja, serta } \\
\text { laporan } \\
\text { keuangan akhir }\end{array}$ \\
\hline & & Inventaris & $\begin{array}{l}\text { Membantu } \\
\text { pengelolaan } \\
\text { inventaris desa }\end{array}$ \\
\hline $\begin{array}{l}\text { Gutama et al } \\
{[31]}\end{array}$ & $\begin{array}{l}\text { Aplikasi } \\
\text { website }\end{array}$ & $\begin{array}{l}\text { Penjadwalan } \\
\text { dan absensi } \\
\text { kegiatan desa }\end{array}$ & $\begin{array}{l}\text { Memudahkan } \\
\text { proses } \\
\text { pencatatan } \\
\text { absensi pada } \\
\text { kegiatan banjar }\end{array}$ \\
\hline $\begin{array}{l}\text { Topohudoyono } \\
\text { dan Budiyono } \\
{[32]}\end{array}$ & $\begin{array}{l}\text { Aplikasi } \\
\text { website }\end{array}$ & $\begin{array}{l}\text { Pelayanan } \\
\text { publik (e- } \\
\text { government) }\end{array}$ & $\begin{array}{l}\text { Membantu } \\
\text { kegiatan } \\
\text { operasional } \\
\text { pelayanan } \\
\text { publik untuk } \\
\text { masyarakat } \\
\text { desa }\end{array}$ \\
\hline $\begin{array}{l}\text { Romadhan dan } \\
\text { Rusmana [29] }\end{array}$ & $\begin{array}{l}\text { Media } \\
\text { sosial }\end{array}$ & Promosi desa & $\begin{array}{l}\text { Membantu } \\
\text { mempromosika } \\
\mathrm{n} \text { objek wisata } \\
\text { melalui } \\
\text { unggahan pada } \\
\text { media sosial } \\
\text { oleh berbagai }\end{array}$ \\
\hline
\end{tabular}

Kadek Darmaastawan: Optimasi Peran Desa Adat...

\begin{tabular}{|c|c|c|c|}
\hline & & & $\begin{array}{l}\text { elemen } \\
\text { masyarakat }\end{array}$ \\
\hline $\begin{array}{l}\text { Aprianto et al } \\
\text { [33] }\end{array}$ & $\begin{array}{l}\text { Aplikasi } \\
\text { website }\end{array}$ & $\begin{array}{l}\text { Penjadwalan } \\
\text { tugas } \\
\text { perangkat } \\
\text { desa }\end{array}$ & $\begin{array}{l}\text { Meningkatkan } \\
\text { kinerja } \\
\text { pelayanan } \\
\text { publik serta } \\
\text { disiplin waktu } \\
\text { dengan } \\
\text { menjadwalkan } \\
\text { tugas-tugas } \\
\text { perangkat desa }\end{array}$ \\
\hline $\begin{array}{l}\text { Samodra et al } \\
{[34]}\end{array}$ & $\begin{array}{l}\text { Aplikasi } \\
\text { website }\end{array}$ & UMKM & $\begin{array}{l}\text { Membantu } \\
\text { mempromosika } \\
\text { n UMKM serta } \\
\text { meningkatkan } \\
\text { pengetahuan } \\
\text { dan } \\
\text { keterampilan } \\
\text { SDM dalam } \\
\text { pemanfaatan } \\
\text { media berbasis } \\
\text { web }\end{array}$ \\
\hline Abidin et al [35] & $\begin{array}{l}\text { Media } \\
\text { Sosial }\end{array}$ & UMKM & $\begin{array}{l}\text { Memanfaatkan } \\
\text { media sosial } \\
\text { sebagai sarana } \\
\text { pemasasaran } \\
\text { produk } \\
\text { UMKM di } \\
\text { masa pandemi } \\
\text { COVID-19 }\end{array}$ \\
\hline $\begin{array}{l}\text { Susila dan Arsa } \\
{[25]}\end{array}$ & $\begin{array}{l}\text { Aplikasi } \\
\text { mobile } \\
\text { (Augment } \\
\text { ed } \\
\text { Reality) }\end{array}$ & Objek wisata & $\begin{array}{l}\text { Menggunakan } \\
\text { teknologi } \\
\text { Augmented } \\
\text { Reality sebagai } \\
\text { media } \\
\text { pengenalan } \\
\text { bangunan adat } \\
\text { Desa } \\
\text { Penglipuran }\end{array}$ \\
\hline $\begin{array}{l}\text { Sidharta dan } \\
\text { Wati [36] }\end{array}$ & $\begin{array}{l}\text { Aplikasi } \\
\text { desktop }\end{array}$ & Urunan & $\begin{array}{l}\text { Memanfaatkan } \\
\text { teknologi } \\
\text { informasi } \\
\text { untuk } \\
\text { mempermudah }\end{array}$ \\
\hline
\end{tabular}

Sebagian besar penelitian terdahulu menyebutkan pemanfaatan teknologi informasi di desa memberikan dampak yang positif bagi desa [29], [32]-[35]. Lebih lanjut disebutkan pada penelitian [31], dampak positif tersebut tidak hanya dirasakan oleh desa atau perangkat desa saja, melainkan dirasakan pula oleh warga desa. Kajian yang dilakukan memiliki tujuan untuk memperoleh potensi teknologi informasi yang dapat diterapkan di desa, khususnya Desa Adat di Bali, yang mampu mengoptimalkan peran Desa Adat di Bali untuk menjaga kelestarian budaya melalui kegiatan adat. Mengingat masih minimnya penerapan teknologi informasi pada bidang budaya tradisional Bali, sehingga perlu diterapkan teknologi informasi yang dapat melestarikan budaya Bali [37]. Pernyataan tersebut juga didukung dengan banyaknya penelitian maupun artikel yang membahas tentang pemanfaatan teknologi informasi di Desa Adat di Bali pada 
berbagai bidang [38]-[43], namun masih sedikit yang mengarah ke budaya tradisional Bali.

Lebih lanjut, untuk mengetahui perkembangan terkini terkait pemanfaatan teknologi informasi di Desa Adat di Bali pada bidang budaya, seperti kegiatan adat, penelitian ini juga melakukan survei secara online. Survei yang dilakukan melibatkan responden sebanyak 78 orang dari Desa Adat yang berbeda satu dengan yang lainnya. Pemanfaatan teknologi informasi yang dimaksud meliputi teknologi informasi pada platform website, media sosial, atau aplikasi smartphone khusus Desa Adat untuk mengelola kegiatan adat.

\section{A. Pemanfaatan Teknologi Informasi serta Penyebaran} Informasi Kegiatan Adat

Survei pemanfaatan teknologi informasi untuk penyebaran informasi kegiatan adat terdiri dari tujuh buah pertanyaan yang memiliki jawaban Ya dan Tidak. Tabel 2 menyajikan pertanyaan serta hasil survei terkait dengan pemanfaatan teknologi informasi untuk penyebaran informasi kegiatan adat.

TABEL II

PEMANFAATAN TEKNOLOGI INFORMASI UNTUK MENYEB ARKAN INFORMASI KEGIATAN ADAT

\begin{tabular}{|c|c|c|c|}
\hline Kode & Pertanyaan & $\begin{array}{c}\mathbf{Y a} \\
(\%)\end{array}$ & $\begin{array}{c}\text { Tidak } \\
(\%)\end{array}$ \\
\hline Q1 & $\begin{array}{l}\text { Apakah desa adat anda } \\
\text { memiliki website? }\end{array}$ & 15.4 & 84.6 \\
\hline Q2 & $\begin{array}{l}\text { Apakah anda memperoleh } \\
\text { informasi terkait kegiatan } \\
\text { adat melalui website desa adat } \\
\text { anda? }\end{array}$ & 14.1 & 85.9 \\
\hline Q3 & $\begin{array}{l}\text { Apakah anda memperoleh } \\
\text { informasi terkait kegiatan } \\
\text { adat berupa pesuan-pesuan } \\
\text { banjar melalui website desa } \\
\text { adat anda? }\end{array}$ & 2.6 & 97.4 \\
\hline Q4 & $\begin{array}{l}\text { Apakah anda memperoleh } \\
\text { informasi terkait kegiatan } \\
\text { adat berupa sumbangan atau } \\
\text { urunan adat melalui website } \\
\text { desa adat anda? }\end{array}$ & 1.3 & 98.7 \\
\hline Q5 & $\begin{array}{l}\text { Apakah anda memperoleh } \\
\text { informasi terkait kegiatan } \\
\text { adat melalui media sosial desa } \\
\text { adat anda? }\end{array}$ & 34.6 & 65.4 \\
\hline Q6 & $\begin{array}{l}\text { Apakah anda memperoleh } \\
\text { informasi terkait kegiatan } \\
\text { adat berupa pesuan-pesuan } \\
\text { banjar melalui media sosial } \\
\text { desa adat anda? }\end{array}$ & 28.2 & 71.8 \\
\hline Q7 & $\begin{array}{l}\text { Apakah anda memperoleh } \\
\text { informasi terkait kegiatan } \\
\text { adat berupa sumbangan atau } \\
\text { urunan adat melalui media } \\
\text { sosial desa adat anda? }\end{array}$ & 32.1 & 67.9 \\
\hline
\end{tabular}

Hasil survei yang disajikan pada Tabel 2 menunjukkan terdapat sedikit Desa Adat di Bali yang telah memiliki website serta memanfaatkannya untuk menyebarkan informasi kegiatan adat, namun masih belum optiomal.

\section{Penggunaan Media Sosial di Desa Adat di Bali}

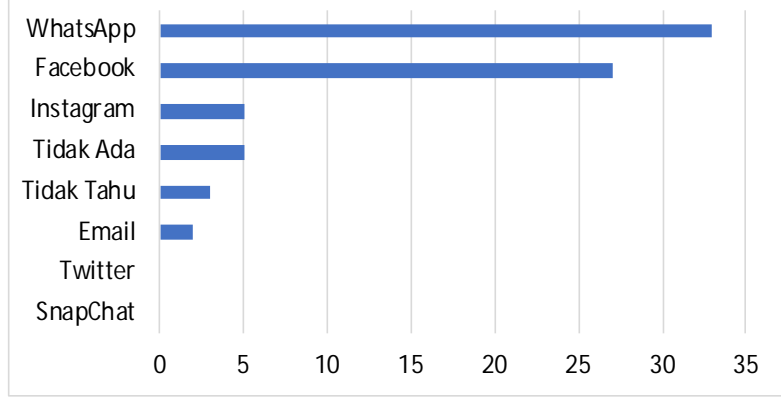

Gambar 1: Penggunaan Media Sosial di Desa Adat di Bali

Hasil survei juga menunjukkan terdapat Desa Adat di Bali yang telah memanfaatkan media sosial untuk menyebarkan informasi kegiatan adat. Gambar 1 menunjukkan data penggunaan media sosial di Desa Adat di Bali untuk berkomunikasi dengan krama desa adalah WhastApp yang memiliki jumlah terbanyak, diikuti oleh Facebook pada posisi kedua, dan Instagram pada posisi ketiga.

Secara kesuluruhan, rata-rata pemanfaatan teknologi informasi untuk menyebarkan informasi kegiatan adat berdasarkan survei yang dilakukan disajikan dalam bentuk grafik yang dapat dilihat pada Gambar 1:

\section{Rata-rata Pemanfaatan Teknologi Informasi di Desa Adat (\%)}

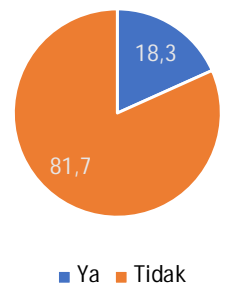

Gambar 2: Rata-rata pemanfaatan teknologi informasi di Desa Adat di Bali

Gambar 1: menunjukkan hanya 18,3\% dari total responden yang sudah memanfaatkan teknologi informasi untuk kegiatan adat. Hal tersebut menunjukkan bahwa masih sedikit Desa Adat di Bali yang memiliki serta memanfaatkan teknologi informasi untuk menyebarkan informasi kegiatan adat ke krama desa. Hal tersebut sangat disayangkan karena dengan memanfaatkan teknologi informasi penyebaran informasi kegiatan adat dapat dilakukan dengan lebih mudah dan dapat diterima lebih cepat oleh krama desa.

\section{B. Pengelolaan Kegiatan Adat}

Survei lanjutan yang lebih rinci terkait dengan pengelolaan kegiatan adat terdiri dari enam buah pertanyaan. Pengelolaan kegiatan adat yang dimaksud adalah seluruh proses kegiatan adat yang ada di Desa Adat. Pengelolaan tersebut meliputi proses penjadwalan serta proses pencatatan kehadiran krama desa pada kegiatan adat. Pengelolaan kegiatan adat juga mencakup proses pembayaran serta pencatatan sumbangan atau urunan adat. Selain itu, survei bagian ini juga bertujuan untuk memperoleh informasi apakah krama desa 
mendapatkan hadiah atau apresiasi jika aktif berpartisipasi di dalam kegiatan adat.

1) Q8: Media apa yang digunakan untuk melakukan penjadwalan kegiatan adat di desa adat anda?: Hasil survei menunjukkan bahwa penjadwalan kegiatan adat yang dilaksanakan di Desa Adat di Bali kebanyakan masih dilakukan secara manual. Hal tersebut dapat dilihat berdasarkan hasil survei yang diperoleh yang disajikan dalam bentuk grafik pada Gambar 3:

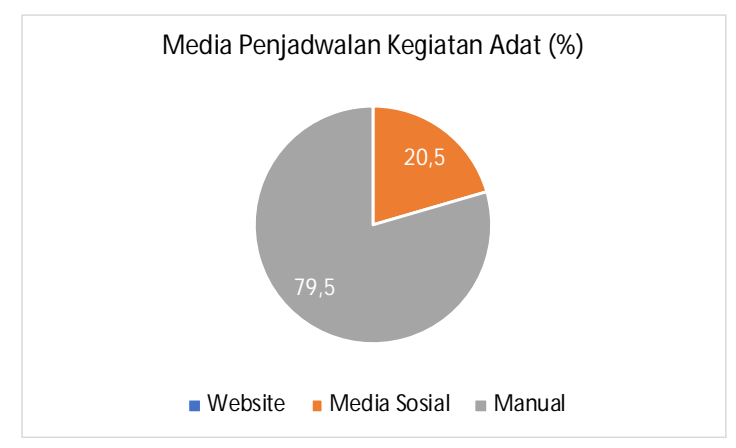

Gambar 3: Media untuk penjadwalan kegiatan adat

Hanya 20\% dari responden yang Desa Adat-nya sudah memanfaatkan teknologi informasi berupa media sosial untuk menjadwalkan kegiatan adat.

2) Q9: Media apa yang digunakan untuk mencatat kehadiran kegiatan adat di desa adat anda?: Hasil survei menunjukkan belum ada Desa Adat di Bali yang mencatat kehadiran warga desa pada kegiatan adat dengan menggunakan teknologi informasi. Data hasil survei terkait hal tersebut dapat dilihat pada Gambar 4:

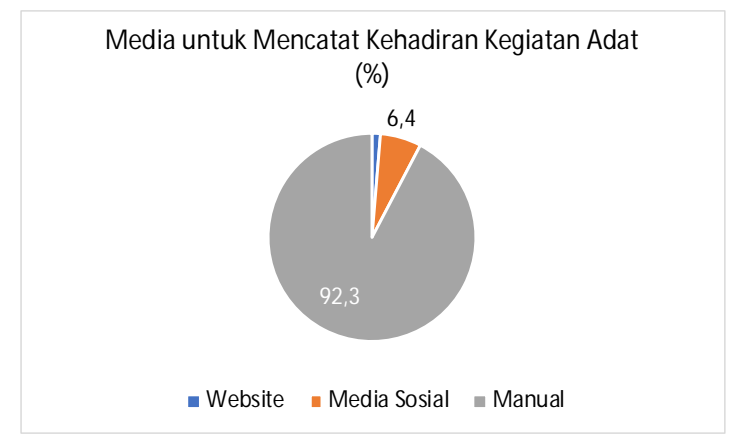

Gambar 4: Media untuk mencatat kehadiran kegiatan adat

Survei menunjukkan, semua Desa Adat responden masih mencatat kehadiran krama desa pada kegiatan adat secara manual. Hal tersebut tentu sangat tidak efektif dan efisien karena memiliki resiko yang besar. Contohnya adalah kesalahan saat mencatat kehadiran atau bahkan catatan kehadiran yang mudah hilang apabila dilakukan secara manual.

Kadek Darmaastawan: Optimasi Peran Desa Adat...
3) Q10: Media apa yang digunakan untuk membayar dan mencatat sumbangan atau urunan adat di desa adat anda?: Hasil survei menunjukkan semua Desa Adat di Bali yang menjadi responden masih menggunakan metode manual dalam membayar dan mencatat sumbangan atau urunan adat. Data hasil survei terkait hal tersebut dapat dilihat pada Gambar 5:

Media Pembayaran dan Pencatatan Sumbangan atau Urunan Adat (\%)

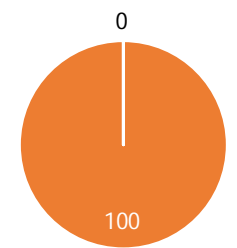

- Transfer Bank - Manual

Gambar 5: Media untuk pembayaran dan pencatatan sumbangan atau urunan adat

Sama halnya dengan penjadwalan serta pencatatan kehadiran kegiatan adat, pembayaran dan pencatatan sumbangan serta urunan adat yang dilakukan secara manual sangat tidak efektif dan efisien. Hal tersebut diakibatkan karena catatan pembayaran tersebut mudah hilang dan memiliki resiko yang sangat besar karena terkait dengan keuangan. Pembayaran secara manual juga tidak efektif dan efisien karena mengharuskan krama desa bertemu langsung dengan perangkat desa yang bersangkutan untuk membayar secara langsung.

4) Q11: Apakah ada hadiah atau apresiasi yang diberikan ke warga adat ketika rajin mengikuti kegiatan adat?: Hasil survei menunjukkan hanya terdapat $10 \%$ dari responden yang Desa Adat-nya memberikan hadiah atau apresiasi bagi krama desa yang aktif berpartisipasi di dalam mengikuti kegiatan adat. Data hasil survei tersebut disajikan pada Gambar 6:

Apresiasi bagi Warga yang Aktif Berpartisipasi pada Kegiatan Adat (\%)

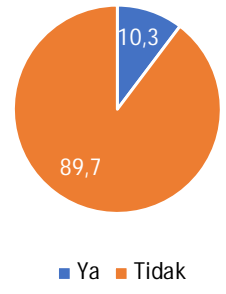

Gambar 6: Apresiasi bagi warga desa yang aktif berpartisipasi dalam kegiatan adat

5) Q12: Apakah ada hadiah atau apresiasi yang diberikan ke warga adat ketika membayar sumbangan atau urunan adat p-ISSN:1693 - 2951; e-ISSN: 2503-2372 
lebih awal?: Hasil survei menunjukkan belum ada Desa Adat responden yang memberikan hadiah atau apresiasi bagi krama desa yang membayar sumbangan atau urunan lebih awal dari krama desa lainnya. Data hasil survei terkait hal tersebut disajikan pada Gambar 7:

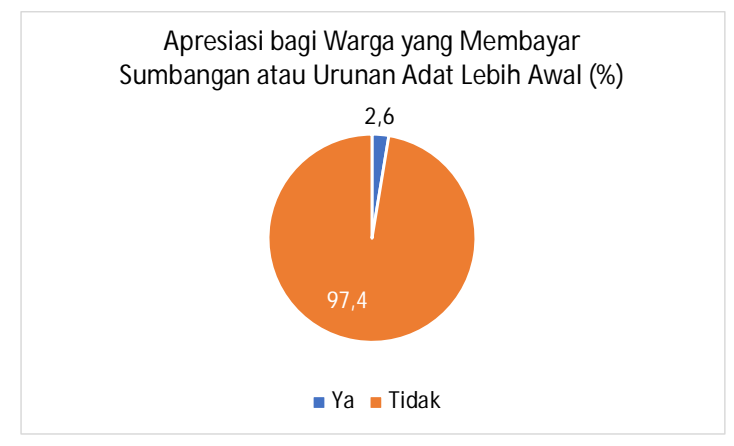

Gambar 7: Apresiasi bagi warga desa yang lebih awal membayar sumbangan atau urunan

6) Q13: Apakah desa adat anda memiliki aplikasi smartphone yang mengelola kegiatan adat seperti penjadwalan, pemeriksaan kehadiran, atau rekap kehadiran?: Hasil survei menunjukkan belum ada Desa Adat responden yang memiliki aplikasi smartphone khusus untuk mengelola seluruh proses kegiatan adat. Data hasil survei terkait hal tersebut disajikan pada Gambar 8:

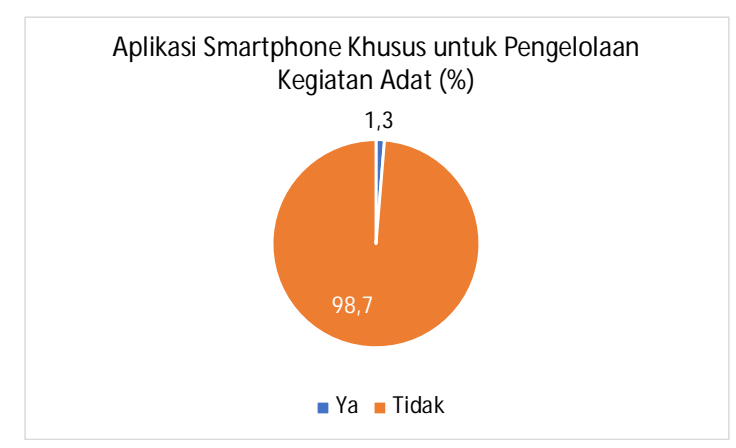

Gambar 8: Aplikasi smartphone khusus untuk mengelola kegiatan adat

Hasil survei yang dilakukan pada penelitian ini serta pernyataan beberapa artikel maupun penelitian lain membuktikan bahwa masih sedikit Desa Adat di Bali yang memanfaatkan teknologi informasi di bidang budaya tradisional Bali, salah satu contohnya adalah untuk megelola kegiatan adat.

Berdasarkan kajian penelitian-penelitian terdahulu, terdapat beberapa potensi teknologi informasi yang dapat dikembangkan untuk mengoptimalkan peran Desa Adat di Bali. Beberapa potensi teknologi informasi yang dapat diterapkan untuk kegiatan adat di Bali berdasarkan kajian yang telah dilakukan adalah sebagai berikut.

- Sistem informasi khusus untuk penjadwalan sekaligus absensi kegiatan adat, seperti ngayah, yang terhubung dengan sistem kependudukan Desa Adat.

- Sistem informasi untuk mengelola urunan atau sumbangan adat juga dapat diterapkan guna memudahkan perangkat Desa Adat dalam memantau urunan atau sumbangan adat.

ISSN 1693 - 2951.
Teknologi informasi tersebut juga dapat dipadukan dengan berbagai teknologi lainnya. Contohnya adalah menerapkan konsep gamification pada penjadwalan ngayah dengan memberikan hadiah berupa poin bagi krama banjar yang hadir atau memberikan hadiah untuk krama banjar yang lebih dulu membayar sumbangan atau urunan. Manfaat yang diperoleh dengan menerapkan teknologi informasi pada kegiatan adat adalah mudahnya pengelolaan kegiatan adat yang dilaksanakan oleh Desa Adat di Bali melalui teknologi informasi. Manfaat tersebut secara tidak langsung juga dapat mengoptimalkan peran Desa Adat dalam melestarikan budaya Bali melalui kegiatan adat.

\section{TANTANGan dan PeKerJaAn Masa DePan}

Berbagai keuntungan yang diperoleh dengan memanfaatkan teknologi informasi di Desa Adat di Bali tentu memiliki dampak positif bagi Desa Adat itu sendiri. Pemanfaatan teknologi tersebut tentu harus menghadapi beberapa tantangan untuk memperoleh hasil yang maksimal. Salah satu contoh tantangan tersebut adalah masih sedikitnya SDM Desa Adat yang mampu mengoperasikan dan menguasai teknologi informasi [32], [44]. Terlebih lagi apabila teknologi informasi yang diterapkan memiliki tampilan yang kurang ditata dengan baik sehingga kurang menarik, maka akan lebih mempersulit SDM dalam mempelajari dan mengoperasikan teknologi informasi tersebut [45]. Oleh karena itu, selain penelitian lebih lanjut untuk menemukan aspek-aspek lain di Desa Adat yang dapat diakomodasi oleh teknologi informasi, penelitian lain juga dapat membahas mengenai user interface dan user experience dari teknologi informasi. Tujuannya adalah agar teknologi informasi dapat diterima dengan baik oleh semua kalangan masyarakat di Desa Adat dan lebih mengoptimalkan desa itu sendiri.

\section{KESIMPULAN}

Desa Adat di Bali masih memiliki berbagai aspek yang dapat diakomodasi oleh teknologi informasi untuk mengoptimalkan peran Desa Adat di Bali dalam melestarikan budaya Bali, salah satunya melalui kegiatan adat. Pernyataan tersebut didukung dengan hasil survei yang dilakukan pada penelitian ini yang menunjukkan hanya $18,3 \%$ dari responden yang Desa Adatnya telah menggunakan teknologi informasi untuk kegiatan adat. Teknologi informasi dapat digunakan untuk memudahkan Desa Adat di Bali dalam mengelola berbagai kegiatan adat, seperti kegiatan gotong-royong di Desa Adat yang dapat dijadwalkan dan dikelola dengan baik menggunakan teknologi informasi, termasuk di dalamnya adalah mencatat kehadiran krama desa pada kegiatan adat. Selain itu proses pembayaran dan pencatatan sumbangan atau urunan adat juga dapat didukung oleh teknologi informasi untuk memudahkan proses tersebut. Tantangan atau permasalahan yang sering dihadapi ketika menerapkan teknologi informasi di Desa Adat adalah kurangnya SDM yang mengerti dan mampu mengoperasikan teknologi informasi. Tantangan tersebut dapat diatasi dengan melakukan pelatihan sehingga SDM dapat menguasai dan siap mengoperasikan teknologi informasi. Dampak dari tantangan tersebut juga dapat diminimalisir dengan memperhatikan user interface dan user experience ketika membangun teknologi informasi yang akan diterapkan di Desa Adat. Teknologi

Kadek Darmaastawan: Optimasi Peran Desa Adat... 
informasi yang diterapkan dengan tepat pada suatu Desa Adat di Bali dan memiliki user interface serta user experience yang baik serta SDM yang mumpuni dapat mengoptimalkan peran Desa Adat tersebut secara signifikan.

\section{REFERENSI}

[1] I. G. P. Suharta, I. G. P. Sudiarta, and I. W. P. Astawa, "Ethnomathematics of Balinese Traditional Houses," Int. Res. J. Eng. IT Sci. Res., vol. 3, no. 4, p. 42, Jul. 2017, doi: 10.21744/irjeis.v3i4.501.

[2] K. Sumadi, "Tourism Development Basis in Traditional Village of Kuta," Int. J. Linguist. Lit. Cult., vol. 2, no. 3, p. 102, 2016, doi: 10.21744/ijllc.v2i3.237.

[3] I. K. D. Laksana, "To the Maintenance of Balinese Culture," Int. J. Linguist. Lit. Cult., vol. 2, no. 2, pp. 64-70, 2016, doi: 10.21744/ijllc.v2i2.122.

[4] E. Yusuf and N. Samsu, "Peran Desa Adat dalam Pengembangan Pariwisata di Bali," Apl. J. Apl. llmu-ilmu Agama, vol. IV, no. 2, pp 202-217, 2003.

[5] B. Post, "Kilas Balkik 2019: Mengawal Budaya Bali, Memberdayakan Desa Adat," 2019.

https://www.balipost.com/news/2019/12/28/96484/MengawalBudaya-Bali,Memberdayakan-Desa...html (accessed Jan. 12, 2021).

[6] I. W. Sudiarsa, A. M. Dirgayusari, and I. G. A. Anom, “Analisi Kebutuhan Sistem Informasi Pada Desa Adat Kesiman Dengan Metode Ward and Peppard," Jurnal Ilmu Komputer dan Sains Terapan, vol. 7, no. 1. pp. 24-29, 2016, doi: 10.31598/sacies.v7i1.111.

[7] P. Aridiantari, I. W. Lasmawan, and I. N. Suastika, "Eksistensi Tradisi dan Budaya Masyarakat Bali Aga pada Era Globalisasi di Desa Trunyan Universitas Pendidikan Ganesha," Ganesha Civ. Educ. J., vol. 2, no. 2, pp. 68-78, 2020, [Online]. Available: https://ejournal2.undiksha.ac.id/index.php/GANCEJ.

[8] K. Darmaastawan, I. M. Sukarsa, and P. W. Buana, "LINE Messenger as a Transport Layer to Distribute Messages to Partner Instant Messaging," Int. J. Mod. Educ. Comput. Sci., vol. 11, no March, pp. 1-9, 2019, doi: 10.5815/ijmecs.2019.03.01.

[9] V. A. Flores, P. A. Permatasari, and L. Jasa, "Penerapan Web Scraping Sebagai Media Pencarian dan Menyimpan Artikel Ilmiah Secara Otomatis Berdasarkan Keyword," Maj. Ilm. Teknol. Elektro, vol. 19 , no. 2 , p. 157 , Dec. 2020 , doi: 10.24843/MITE.2020.v19i02.P06.

[10] I. M. A. Bhaskara, D. M. Wiharta, and O. Saputra, "Perancangan Sistem Penyedia File Sharing dengan Enkripsi URL menggunakan Algoritma Rijndael," Maj. Ilm. Teknol. Elektro, vol. 19, no. 2, p. 171, Dec. 2020, doi: 10.24843/MITE.2020.v19i02.P08.

[11] I. M. Sukarsa, I. K. G. D. Putra, N. P. Sastra, and L. Jasa, “A New Framework for Information System Development on Instant Messaging for Low Cost Solution," TELKOMNIKA, vol. 16, no. 6, pp. 2799-2808, 2018, doi: 10.12928/TELKOMNIKA.v16i6.8614.

[12] S. Sowmya and S. Roja, "A study on advantages and disadvantages of internet," Int. J. Acad. Res. Dev., vol. 2, no. 6, pp. 358-361, 2017.

[13] D. K. dan I. K. Natuna, "Pemanfaatan Teknologi Informasi untuk Meningkatkan Pendapatan Masyarakat Desa,” 2018. https://diskominfo.natunakab.go.id/pemanfaatan-teknologiinformasi-untuk-meningkatkan-pendapatan-masyarakat-desa/ (accessed Jan. 12, 2021).

[14] H. R. Suharno, N. Gunantara, and M. Sudarma, "Analisis Penerapan Metode Scrum Pada Sistem Informasi Manajemen Proyek Dalam Industri \&amp; Organisasi Digital," Maj. Ilm. Teknol. Elektro, vol. 19, no. 2, p. 203, Dec. 2020, doi: 10.24843/MITE.2020.v19i02.P12.

[15] Y. Wang, "Application of Information Technology in Optimizing the Governance of Basic Education Groups," Int. J. Emerg. Technol. Learn., vol. 16, no. 05, p. 281, Mar. 2021, doi: 10.3991/ijet.v16i05.22407.

[16] Y. Khristopher, "Future of Information Technology: Key Trends \& Assumptions," 2020.

https://www.androidheadlines.com/2020/11/future-of-informationtechnology-2020.html\#: :text=Today $\% 2 \mathrm{C}$ the future of

Kadek Darmaastawan: Optimasi Peran Desa Adat... information,be useful for automation purposes\&text=Artificial intelligence $\% 2 \mathrm{C}$ big data $\% 2 \mathrm{C}$ robotics,driving cars $\% 2 \mathrm{C}$ and other innovations (accessed Jan. 12, 2021).

[17] D. G. A. S. Y. Purnama and A. A. I. A. A. Dewi, "Desa adat Dalam Pengelolaan Tanah Adat Bali Berbasis Kebijakan Daerah," Acta Com., vol. 4, no. 2, p. 343, Jul. 2019, doi: 10.24843/AC.2019.v04.i02.p16.

[18] A. O. Suradiva, M. Muhammad, and S. Saryani, "Partisipasi Pemuda Dalam Pengembangan Desa Wisata Guna Meningkatkan Ketahanan Sosial Budaya Masyarakat Desa (Studi di Desa Wisata Batubulan, Sukawati, Gianyar, Bali)," J. Ketahanan Nas., vol. 24, no. 3 , p. 389,2018 , doi: $10.22146 /$ jkn.38371.

[19] A. Hernandi, S. Hendriatiningsih, and A. Budiartha, "MASYARAKAT DAN TANAH ADAT DI BALI (Studi Kasus Kabupaten Buleleng, Provinsi Bali)," J. Sosioteknologi, vol. 7, no. 15 , pp. 517-528, 2008 .

[20] I. K. Meniarta, W. Mas'udi, and A. A. Dwipayana, "Dinamika Sistem Kesejahteraan dan Modal Sosial di Masyarakat Banjar Pakraman-Bali," J. Ilmu Sos. dan Polit., vol. 13, no. 2, pp. 231-248, 2009, doi: https://doi.org/10.22146/jsp.10963.

[21] N. S. E. Kurniawati, "Penerapan banjar suka duka sebagai efisiensi biaya di desa Buduk Bali," J. Ekon. dan Bisnis, vol. 21, no. 1, pp. 159-174, 2018, doi: 10.24914/jeb.v21i1.1037.

[22] A. Adharinalti, "Eksistensi Hukum Adat Dalam Penyelenggaraan Pemerintahan Desa Di Bali," J. Rechts Vinding Media Pembin. Huk. Nas., vol. 1, no. 3, p. 409, 2012, doi:

10.33331/rechtsvinding.v1i3.93.

[23] N. K. P. Noviasi, G. J. Waleleng, and J. R. Tampi, "Fungsi Banjar Adat Dalam Kehidupan Masyarakat Etnis Bali Di Desa Werdhi Agung, Kecamatan Dumoga Tengah, Kabupaten Bolaang Mongondow Provinsi Sulawesi Utara," Acta Diurna Komun., vol. 4, no. 3, pp. 1-10, 2015, [Online]. Available:

https://ejournal.unsrat.ac.id/index.php/actadiurnakomunikasi/article/ view/8289/7848.

[24] N. W. Suarmini, "Peranan "Desa Pakraman "Dalam Memperkuat Ketahanan Sosial Budaya Melalui Konsep Ajaran 'Tri Hita Karana,"” J. Sos. Hum., vol. 4, no. 1, pp. 1-12, 2011, doi: 10.12962/j24433527.v4i1.635.

[25] A. A. N. H. Susila and D. M. S. Arsa, "Aplikasi Augmented Reality Pengenalan Bangunan Adat Desa Penglipuran," J. Media Inform. Budidarma, vol. 4, no. 3, p. 726, 2020, doi: 10.30865/mib.v4i3.2208.

[26] I. G. B. R. Utama, "Keunikan Budaya dan Keindahan Alam sebagai Citra Destinasi Bali menurut Wisatawan Australia Lanjut Usia," J. Kaji. Bali, vol. 06, no. April, pp. 149-172, 2016, [Online]. Available:

http://ojs.unud.ac.id/index.php/kajianbali/article/view/19904.

[27] I. A. S. Devi, D. Damiati, and N. D. M. S. Adnyawati, "Potensi Objek Wisata Edukasi Di Kabupaten Gianyar," J. BOSAPARIS Pendidik. Kesejaht. Kel., vol. 9, no. 2, p. 130, 2018, doi: 10.23887/jjpkk.v9i2.22136.

[28] K. Wijaya, "MASA DEPAN PARIWISATA BALI (PERSPEKTIF PERMASALAHAN DAN SOLISINYA)," J. Ris. Ekon. dan Manaj., vol. 15, no. 1, p. 118, Aug. 2015, doi: 10.17970/jrem.15.150109.ID.

[29] M. I. Romadhan and D. S. A. Rusmana, "Potensi Media Sosial Sebagai Sarana Media Promosi Pariwisata Berbasis Partisipasi Masyarakat," Prosding Semin., pp. 85-90, 2017.

[30] F. Rozi and T. Listiawan, "Pengembangan Website Dan Sistem Informasi Desa Di Kabupaten Tulungagung," JIPI (Jurnal Ilm. Penelit. dan Pembelajaran Inform., vol. 2, no. 2, pp. 107-112, 2017, doi: 10.29100/jipi.v2i2.366.

[31] M. P. Gutama, A. A. K. O. Sudana, and A. A. K. A. C. W, "Rancang Bangun Sistem Manajemen Absensi Kegiatan Banjar Berbasis Web," Merpati, vol. 2, no. 2, pp. 179-187, 2014. T. Topohudoyono and B. Budiyono, "Membangun Layanan Informasi Publik Melalui Fitur-Fitur Website Desa (Kasus di Desa Madukara, Banjarnegara, Jawa Tengah)," J. Komun., vol. 12, no. 1, pp. 1-18, 2017, doi: 10.20885/komunikasi.vol12.iss1.art1. R. Aprianto, Wulandari, and N. Hafifah, "Pengembangan Aplikasi Web Mobile Penjadwalan Tugas Aparatur Desa Untuk

p-ISSN:1693 - 2951; e-ISSN: 2503-2372 
Meningkatkan Layanan Masyarakat," J. Teknol. Komput. dan Sist. Inf., vol. 01, no. 03, pp. 81-86, 2018, [Online]. Available: http://ojs.stmikpringsewu.ac.id/index.php/jtksi/article/view/663. [34] J. Samodra, A. S. Pahlevi, and Y. A. L. Hermanto, "Pasar Desa Digital Berbasis Web Sebagai Media Promosi Bagi Umkm," $J$. KARINOV, vol. 2, no. 3, p. 177, 2019, doi: 10.17977/um045v2i3p177-180.

[35] Z. Abidin Achmad, T. Zendo Azhari, W. Naufal Esfandiar, N. Nuryaningrum, A. Farah Dhilah Syifana, and I. Cahyaningrum, "Pemanfaatan Media Sosial dalam Pemasaran Produk UMKM di Kelurahan Sidokumpul, Kabupaten Gresik," J. Ilmu Komun., vol. 10, no. 1, pp. 17-31, 2020, doi: 10.15642/jik.2020.10.1.17-31.

[36] I. Sidharta and M. Wati, "Perancangan Dan Implementasi Sistem Informasi Urunan Desa (URDES) Berdasarkan Pada Pajak Bumi Dan Bangunan," J. Comput. Bisnis, vol. 9, no. 2, pp. 95-107, 2015.

[37] AA. K. Oka Sudana, "Jelajah Implemetasi Teknologi Informasi dalam Bidang Budaya Bali dan Agama Hindu," UNIVERSITAS UDAYANA, 2015. https://www.unud.ac.id/in/berita91-JelajahImplemetasi-Teknologi-Informasi--dalam-Bidang-Budaya-Balidan-Agama-Hindu.html (accessed Apr. 02, 2021)

[38] I. W. Ardiyasa, I. K. A. A. Arianto, and N. L. G. G. Praharsini, "Penerapan dan Pelatihan Teknologi Informasi Pada Perangkat Desa di Kantor Kepala Desa Pengeragoan Jembrana Bali," WIDYABHAKTI J. Ilm. Pop., vol. 2, no. 2, pp. 100-106, 2020.

[39] I. W. Sudiarsa and I. G. A. Anom, "PERANCANGAN SISTEM INFORMASI E-ARSIP DI DESA ADAT KESIMAN DENGAN METODE SEKUENSIAL LINEAR," J. Teknol. Inf. dan Komput., vol. 6, no. 3, pp. 260-267, 2020.

[40] B. P. W. Nirmala and S. Lavianto, "PEMANFAATAN DIGITAL ENABLER DALAM TRANSFORMASI PEMASARAN DESA WISATA BERBASIS KERAKYATAN DI BALI," J. Teknol. Inf. dan Komput., vol. 5, no. 1, pp. 148-157, 2019, [Online]. Available: bagus.p.wahyu@gmail.com1) sephylavianto59@gmail.com2).

[41] D. Dewa Wiguna and Sudiarta Wiguna, "Bali Harapkan Digitalisasi Pelaku Usaha Desa Wisata," Antara Bali, 2017.

https://bali.antaranews.com/berita/105604/bali-harapkandigitalisasi-pelaku-usaha-desa-wisata (accessed Apr. 02, 2021).

[42] I. N. T. A. Putra, K. S. Kartini, and L. G. K. Dewi, "Sentuhan Digital Bisnis (Teknologi Informasi) pada UMKM Studi Kasus: Pemasaran Produk Adi Upakara," Int. J. Nat. Sci. Eng., vol. 3, no. 2, pp. 79-84, 2019, doi: http://dx.doi.org/10.23887/ijnse.v3i2.22225.

[43] I. A. W. SUGIANINGRAT, P. K. A. SANJAYA, and P. NURATAMA, "Pemberdayaan Pengelola Lembaga Ekonomi Komunitas Adat Melalui Penguasaan Teknologi Informasi Di Desa Jungut Kabupaten Klungkung, Bali," J. Sewaka Bhakti, vol. 2, no. 1, pp. 21-34, 2019, doi: 10.32795/jsb.v2i1.288.

[44] D. Praditya, "Pemanfaatan Teknologi Informasi dan Komunikasi (TIK) di Tingkat Pemerintahan Desa," J. Penelit. Komun., vol. 17, no. 2, pp. 129-140, 2014, doi: 10.20422/jpk.v17i2.12.

[45] N. Luh Putri Ari Wedayanti, N. Kadek Ayu Wirdiani, and I. Ketut Adi Purnawan, "Evaluasi Aspek Usability pada Aplikasi Simalu Menggunakan Metode Usability Testing," J. Ilm. Merpati (Menara Penelit. Akad. Teknol. Informasi), vol. 7, no. 2, p. 113, 2019, doi: 10.24843/jim.2019.v07.i02.p03. 